\title{
Analysis of the Correlations Between Public Capital Investments and Economic Development in Romania
}

\author{
Anca-Ştefania Sava, University of Iasi, Romania \\ Bogdan-Gabriel Zugravu, University of Iaşi, Romania
}

\begin{abstract}
This article aims to address the correlations between public capital investments and economic development in Romania. Firstly, it presents a brief literature review on the subject proposed for analysis, under which it can be assumed that public capital investments have a positive impact on production, employment, private sector and thus contribute to economic development. Also, we found some heterogeneity of results across country, regions and sectors. Secondly, it analysis the evolution of public capital investments and gross domestic product during 2006-2009 and also tests the relationship between this two variables, using a correlation coefficient, based on data from the general consolidated budget provided by The Ministry of Public Finance and also statistical data on GDP from National Institute of Statistics.
\end{abstract}

\section{Keywords}

Public capital investment, economic development, the general consolidated budget

JEL Code: H54, G23, O47

\section{Literature Review on the Correlation Between Public Capital Investments and Economic Development}

The purpose of this literature review is to present a selection of studies and reports which show the positive and also the negative correlations between public capital investments and economic growth, studies that were based on results obtained in the respective countries.

Discussions on the effects of infrastructure had increased especially after 1989, with the assumption made by David Alan Aschauer, that the decline in productivity of public services is crucial to explain the general decline in growth. With his work as a support results in which analyzed the economic situation of the United States, Aschauer noted that an increase of $1 \%$ of the stock of public capital generates a $0.4 \%$ increase in productivity ${ }^{1}$. As a consequence, sustained participation of state capital is able to contribute to economic growth. Various empirical studies show the importance of public capital composition on growth of different regions, as some components have greater direct effects on the production process than others. An example is the study of Mastromarco and Ulrich (2006), on the case of Italy, which shows that capital investment include a basic infrastructure and other non-basic type. The first category included: roads and airports, railways and metros, ports, power lines and water, telecommunications, while the seconds include hospitals, public buildings etc ${ }^{2}$.

\footnotetext{
${ }^{1}$ Aschauer, D.A. (2000), Do states optimize? Public capital and economic growth, The Annals of Regional Science 34, p.361

${ }^{2}$ Mastromarco, C. and Woitek, U. (2006), Public infrastructure investment and efficiency in Italian regions, Journal of Productivity Analysis 25, p.2
} 
The study also shows that a $10 \%$ increase in infrastructure investment can generate a change in the economic efficiency of different regions, with $4 \%$ (for basic infrastructure) and $-4 \%$ for the non-core, so the effects are symmetrical. On the other hand, shows that increased investment in infrastructure increases non-basic differences between south and north. Issues of public capital productivity are of interest for many economists. Such a study is the one of Mittnik et al. (2001) on a panel of 6 countries (Canada, France, Britain, Japan, Netherlands and Germany), under which an increase in public investment leads to a higher rate of marginal productivity of private capital and increase long-term private investment ${ }^{3}$.

Another economist, Yakita (2004), found that public capital accumulation expands the possibility of production in the private sector, while public demand for investment goodsprice elasticity of demand affects total ${ }^{4}$.

Some economists have analyzed the economic effect on short and long term of a permanent increase in public capital financed at the expense of establishing the minimum income tax. An increase in public capital investment has a positive effect both on capital stock, but also to employment, in the short term. This multiplier effect is generated by an increase in the marginal productivity of capital and labor, as the wealth reduction due to higher taxes 5 .

Another study concerned the causal effect of the public capital stock on production was carried out by Kawaguchi et al. (2009), using as natural experiment the electoral reform in Japan in 1994, which resulted in changes in public capital between the regions of the country. Empirical testing can not reject the null hypothesis that public capital is not productive based on estimates from this experiment. Study results indicate that an increase of $10 \%$ of public capital is increasing the output per hour of work by $0.4 \%$.

Also, some studies look for the side effects of public investment on private capital and employment. Such a study is the one conducted by Deliktas et al. (2009), on the case of Turkey, which emphasizes positive and negative long-term effects of public capital installed outside of regions over others. Thus, in the Marmara region, which represents $60 \%$ of private manufactured in Turkey and that attracts most public investment, around 30\%, the effects are positive, while in the south-east Anatolia, the effects are negative ${ }^{7}$. These cases are explained by the mobility of production factors, from the less developed to developed ones. Moreover, the employment rate is $9.7 \%$ to $-5.5 \%$ in the Marmara and South-eastern Anatolia.

Alonso-Carrera (2009) identified the positive spillover effects of public capital for almost all regions of Spain, with differences in per capita production in various regions ${ }^{8}$.

Toshiki Tama (2009) showed that public investments enhance economic growth, because it stimulates demand for intermediate goods, and also increasing profits for the sector companies. Therefore, this increase raises the interest market rate and thus leads to economic growth ${ }^{9}$.

There are studies showing a negative relationship between public capital expenditure and long-term growth. Typical is the study by Ghosh and Gregoriou (2009) for 15 industrialized

\footnotetext{
${ }^{3}$ Mittnik, S. and Neumann, T. (2001), Dinamic effects of public investment: vector autoregressive evidence from six industrialized countries, Empirical Economics 26, p.440

${ }^{4}$ Yakita, A. (2004), Elasticity of substitution in public capital formation and economic growth, Journal of Macroeconomics 26, p.3

${ }^{5}$ Coto-Martinez, J. (2006), Public capital and imperfect competition, Journal of Public Economics 90, p.353

${ }^{6}$ Kawaguchi, D., Ohtake, F., Tamada, K. (2009), The productivity of public capital: Evidence from Japan's 1994 electoral reform, Journal of The Japanese and International Economies 23, p.339

${ }^{7}$ Deliktas, E. et al. (2009), The spillover effects of public capital on the Turkish private manufacturing industries in the geographical regions, Annals of Regional Science, 43, p.376

${ }^{8}$ Alonso-Carrera, J. et al. (2009), Macroeconomic effects of the regional allocation of public capital formation, Regional Science and Urban Economics 39, p.571

${ }_{9}$ Toshiki, T. (2009), Variety of products, public capital, and endogenous growth, Economic Modelling 26, p. 253
} 
countries. For Brazil and Thailand, public capital expenditure had a significant negative effect, while current expenditure has a significant positive role on economic growth; on the other hand, for countries like Sudan and Zimbabwe none of the two types of expenditure has a substantial impact on growth ${ }^{10}$.

The correlation public investment - economic development was analyzed for the purposes of the negative impact of inadequate investment on the labor market.

Everaert and Heylin (2004) analyzed the situation of Belgium in the period 1965-1966, and their views have shown a clear negative effect between public capital and employment, whereas an increase in public capital stock by $1 \%$ reduces the employment in the private sector by around $0.32 \%$, indicating a substitution relationship between two variables ${ }^{11}$.

In recent years, studies focused not so much on public investment to confirm the correlation of public capital investments - economic growth, but on measuring the intensity of this correlation. The results of these studies are somewhat different, some identifying a strong correlation, while others advocate a weaker correlation between public investment and capital growth. For example, the study of Romp and de Haan (2007) supports the idea of an impact on growth capital expenditures substantially lower than the effects mentioned by Aschauer (2000) and some heterogeneity, meaning that the effects differ across countries, the level of regions or sectors.

Also, research conducted by Hulten (1996) showed a weak correlation of public capital expenditure on economic development. Another study by Rioja, also in 1998, using as panel 7 Latin American countries, concluded that infrastructure investments have positive effects on gross domestic product and wider on private investment.

According to a study by Shioji (2001) with the USA situation models (1960-1988) and Japan (1955-1993) found that infrastructure was a modest contribution to economic growth of $4 \%$ for the U.S. and 19\% for Japan ${ }^{12}$. Effects identified for the component „Education” were positive, as well as for „Agriculture and Fisheries”, while the „National land conservation” the effects were insignificant.

International Monetary Fund (2004) report shows that empirical research confirms the positive correlation between public expenditure and growth capital. Of 102 studies that have led to investment in infrastructure at the impact on productivity and economic growth, 53\% showed a positive impact, $42 \%$ one limited, and in $5 \%$ of these studies the impact was negative.

The research includes studies conducted in 30 different countries (including developing countries), 41 studies from the United States, 19 studies in Spain and 12 studies in countries like Argentina, Brazil, Colombia, India and the Philippines.

The individual studies for each country show different results. While in the United States $54 \%$ of the studies did not reveal a significant relationship, in developing states the effect was $100 \%$ positive, which shows that infrastructure investment plays a key role in promoting growth and productivity and reducing disparities between rich and poor regions. Studies conducted in Spain confirmed the extent of $74 \%$ significant contribution of infrastructure on economic performance. Moreover, Spain has received from EU cohesion funds to cover the disparities between regions and within them.

Based on these studies we can say that there are many positive effects of public capital investments on economic development.

\footnotetext{
${ }^{10}$ Gregoriou, A. and Ghosh, S. (2009), On the heterogeneous impact of public capital and current spending on growth across nations, Economics Letters 105, p.34

${ }^{11}$ Everaert, G. and Heylen, F. (2004), Public capital and long-term labour market performance in Belgium, Journal of Policy Modeling 26, p. 103

12 Shioji, E. (2001), Public capital and economic growth: a convergence approach, Journal of Economic Growth 6, p.219
} 


\section{Testing the Correlation Between Public Capital Investments and Economic Development in Romania}

In Romania there are no empirical studies to test the correlation between public capital investment and economic growth.

Based on the data from the general consolidated budget provided by the Ministry of Public Finance and also on data from National Institute of Statistics, we tested, using the correlation coefficient, the relationship between the public capital investments and gross domestic product in Romania, during 2006-2009.

The values for public capital expenditure and gross domestic product are presented in Table no. 1.

Table no. 1: Evolution of Public Capital Expenditure and GDP in Romania During 2006-2009

\begin{tabular}{|l|l|l|l|l|}
\hline & $\mathbf{2 0 0 6}$ & $\mathbf{2 0 0 7}$ & $\mathbf{2 0 0 8}$ & $\mathbf{2 0 0 9}$ \\
\hline $\begin{array}{l}\text { Total public expenditure } \\
\text { (million lei) }\end{array}$ & $112,626.3$ & $136,556.5$ & 189,122 & $193,025.4$ \\
\hline GDP (million lei) & $344,650.6$ & $412,761.5$ & 503,959 & 491,273 \\
\hline $\begin{array}{l}\text { Public capital expenditure } \\
\text { (million lei): }\end{array}$ & 12,717 & $14,410.4$ & $23,203.4$ & $23,175.3$ \\
\hline \% in total public expenditure & 11.29 & 10.55 & 12.26 & 12.00 \\
\hline$\%$ in GDP & $\mathbf{3 . 7}$ & $\mathbf{3 . 5}$ & $\mathbf{4 . 6}$ & $\mathbf{4 . 7}$ \\
\hline
\end{tabular}

(Source: Developed by authors, based on budget implementation in the years 2006-2009, available on the website of the Ministry of Public Finance and also on data from National Institute of Statistics)

Looking at the general consolidated budget in 2006-2009 there were found increased values for public capital expenditure for the period under review, with $0.82 \%$ higher in 2009 compared with 2006, their share in GDP and in total public expenditure in 2009 reaching $4.7 \%$, respectively $12 \%$, which reflects an improvement in expenditure policy by channeling public funds to support economic growth.

Capital expenditures had lower values compared to the original provisions set out in budgets. Thus, in 2008 , they represented only $4.6 \%$ of GDP, from $5.2 \%$ originally scheduled in the general consolidated budget. The bulk of investment spending have been made from internal sources (state budget and local budgets), draws support from structural and cohesion funds representing $€ 178$ million (6\% of the amount assigned), given that EU allocations were about $€ 3.1$ million, accumulated in the years 2007 and 2008 .

In 2009 , in the consolidated budget we could see that the largest amounts, representing public capital investment, were included in the budget of the central administrative territorial units (11,427.5 million lei) and in the budget of the National Company of Motorways and National Roads (5519.5 million lei). As noted in the table, the state capital participation has a low share in total public expenditure, whereas the mostly took the form of grants, allowances, bonuses, loans with subsidized interest and other reimbursable amounts.

Taking into account previous values given in Table no.1 for public capital expenditure and GDP for the period 2006-2009, it was calculated the correlation coefficient between these two variables. Results are shown in Table no. 2.

Table no. 2: Calculation of Correlation Coefficient Between Public Capital Investment (x) and GDP (y) for Romania During 2006-2008

\begin{tabular}{|l|l|}
\hline $\bar{X}(\%)$ & 24.74 \\
\hline
\end{tabular}




\begin{tabular}{|l|l|}
\hline $\bar{y}(\%)$ & 13.11 \\
\hline$\sigma^{2}(x)$ & 688.24 \\
\hline$\sigma^{2}(y)$ & 123.06 \\
\hline$\sigma(x)$ & 26.23 \\
\hline$\sigma(y)$ & 11.09 \\
\hline $\operatorname{cov}(x, y)$ & 319.23 \\
\hline$\rho(x, y)$ & 0.0037 \\
\hline \multicolumn{2}{|c|}{ (Source: Developed by authors) } \\
\hline
\end{tabular}

The data show a positive correlation, but poor between the two variables, namely the fact that about $0.37 \%$ of GDP growth is associated with or explained by increased public spending capital.

Table no. 3: Evolution of Public Capital Investment Reflected in the State Budget, in Key Economic Sectors, in Romania, During 2006-2009

-thousands lei-

\begin{tabular}{|l|r|r|r|r|}
\hline & $\mathbf{2 0 0 6}$ & $\mathbf{2 0 0 7}$ & $\mathbf{2 0 0 8}$ & $\mathbf{2 0 0 9}$ \\
\hline Mining, manufacturing and construction \\
\hline Total public expenditure & 621,366 & 506.311 & 474950 & 360007 \\
\hline Public capital expenditure & 0 & 0 & 0 & 0 \\
\hline Agriculture, forestry, fishing and hunting \\
\hline Total public expenditure & $3,145,768$ & $3,729,783$ & $6,331,897$ & $8,392,664$ \\
\hline Public capital expenditure & 197,269 & 210,000 & 263,000 & 81,266 \\
\hline Transports \\
\hline Total public expenditure & $4,077,567$ & $5,197,122$ & $7,011,205$ & $8,712,444$ \\
\hline Public capital expenditure & 69,644 & 19,190 & 13,920 & 17,532 \\
\hline Comunications & 12,110 & 27,980 & 27,308 & 310,357 \\
\hline Total public expenditure & 1,480 & 3,370 & 7,900 & 38,800 \\
\hline Public capital expenditure & 81,093 & 80,717 & 117,640 & 103,974 \\
\hline Research and development on economic sector \\
\hline Total public expenditure & 357 & 415 & 200 & 384 \\
\hline Public capital expenditure & 437,098 & 641,395 & 806,393 & $1,057,586$ \\
\hline Fuels and Energy & 0 & 0 & 0 & 0 \\
\hline Total public expenditure &
\end{tabular}

(Source: Developed by authors from state budget data for the years 2006-2009)

As seen from the table above, in the state budget (data are available for all economic sectors at this level) the increased participation from the state capital has been directed by the transport sector. Moreover, its budget was the greatest under the review period. It is noted, however, a decrease of public capital investment from year to year, from 69,644 thousand lei (2006) to 17,532 thousand lei (2009).

Public capital expenditure is concerned to modernization and revitalization of rail transport activities, upgrading of airports and transportation base. 


\section{Conclusions}

Public capital represents, according to the World Bank (1994), the „wheels” - if not, „the engine" - of the economic activity.

Public capital expenditure is a key driver of growth contributing to poverty alleviation, improving living standards and business productivity, households and government services. Starting from research conducted by Aschauer, the role of public capital on growth process began to be a topic of real interest.

Most empirical studies have shown a positive relationship between public capital investments and economic development and also heterogeneity of public investment effects across countries, sectors or regions.

Looking at the executions of the general consolidated budget for the years 2006-2009, we have seen that the largest public capital expenditure was targeted to the transport industry. Our research found that in Romania there are no empirical studies to test the correlation between public spending capital and economic growth, public capital weights in total expenditure incurred by the state is low and down from year to year.

After calculating the correlation coefficient between public capital investment and gross domestic product during 2006-2009, there was found a weak correlation, but a positive one, which shows that an increase of state capital participation is likely to contribute to a low proportion to economic development.

\section{Acknowledgements}

I am grateful to "Alexandru Ioan Cuza" University of Iasi, for financial support of this article, as beneficiary of a grant POSDRU/88/1.5/S/47646, named "Studii doctorale: portal spre o carieră de excelență în cercetare şi societatea cunoaşterii", cofinanced from the European Social Fund, within the Sectoral Operational Programme Human Resources Development 2007-2013, the project implementation period being 36 months, from March 1, 2010, until February 28, 2013.

\section{References}

1. Alonso-Carrera, Jaime et al. (2009), Macroeconomic effects of the regional allocation of public capital formation, Regional Science and Urban Economics 39, 563-574

2. Aschauer, D.A. (2000), Do states optimize? Public capital and economic growth, The Annals of Regional Science 34, 343-363

3. Coto-Martinez, J. (2006), Public capital and imperfect competition, Journal of Public Economics 90, 349-378

4. Deliktas Ertugrul et al. (2009), The spillover effects of public capital on the Turkish private manufacturing industries in the geographical regions, Annals of Regional Science 43, 365-378

5. Everaert, G. and Heylen, F. (2004), Public capital and long-term labour market performance in Belgium, Journal of Policy Modeling 26, 95-112

6. Gregoriou, A. and Ghosh, S. (2009), On the heterogeneous impact of public capital and current spending on growth across nations, Economics Letters 105, 32-35

7. Kawaguchi, D., Ohtake, F., Tamada, K. (2009), The productivity of public capital: Evidence from Japan's 1994 electoral reform, Journal of The Japanese and International Economies 23, 332-343

8. Mastromarco, C. and Woitek, U. (2006), Public infrastructure investment and efficiency in Italian regions, Journal of Productivity Analysis 25, 57-65

9. Ministerul Finanțelor Publice, Execuțiile bugetului general consolidat pe anii 2006-2009

10. Ministerul Finanțelor Publice, Bugetul de stat pe anii 2006-2009

11. Mittnik, S. and Neumann, T. (2001), Dinamic effects of public investment: vector autoregressive evidence from six industrialized countries, Empirical Economics 26, 429-446 


\section{Studies and Scientific Researches - Economic Edition, no. 15, 2010}

12. Shioji, E. (2001), Public capital and economic growth: a convergence approach, Journal of Economic Growth 6, 205-227

13. Statistica Consiliului Concurenței din România, Raportul privind ajutoarele acordate de stat în perioada 2004-2006

14. Toshiki, T. (2009), Variety of products, public capital, and endogenous growth, Economic Modelling 26, 251-255

15. Yakita, A. (2004), Elasticity of substitution in public capital formation and economic growth, Journal of Macroeconomics 26, 391-408

16. www.mfinante.ro

17. www.insse.ro 